\title{
Üç Önemli Kuramcı Üzerinden Alımlama Estetiğinin İncelenmesi ve Bir Uygulama \\ TOLGA KAVALCI*
}

\begin{abstract}
Öz
Alımlama Estetiği, okur merkezli kuramlar içinde birkaç önemli kuramın bir araya gelmesiyle oluşturulmuş bir edebiyat teorisidir. Edebiyata anlam üzerinden yaklaşır. Bu yaklaşımıyla dil felsefesi alanına da girer. En belirgin özelliği ise araştırdı̆̆ı anlam sorununda okuru merkeze yerleştirmesidir. Bu bağlamda yazarı ve metni büyük ölçüde göz ardı eder. Bu çalışmada Alımlama Kuramı́nı üç önemli teorisyeni üzerinden, onların geliştirdiği kuramlara odaklanarak inceledik. Bu kuramcılar Wolfgang Iser, Hans-Robert Jauss ve Stanley Fish'tir. Metot olarak da üç kuramcının kuramları örneklerle açılanmış, daha sonra bu kuramların açılarına ve onlara getirilen eleştirilere değinilmiştir. Alımlama Estetiği'nin edebiyatı tanımlamak hususunda da anlam sorununu çözmek iddiasında da yetersiz kaldığını iddia ediyoruz. Fakat bu araştırmaların kapsamına okuru başarılı bir şekilde dâhil ederek dil felsefesinde ve edebiyat kuramında devrimsel bir yenilik gerçekleştirdiğini ortaya koyuyoruz.
\end{abstract}

Anahtar sözcükler: Alımlama Estetiği, Okur Merkezli Kuramlar, Wolfgang Iser, HansRobert Jauss, Stanley Fish.

\section{THE ANALYSIS OF RECEPTION THEORY THROUGH THREE IMPORTANT THEORISTS AND A SAMPLE}

\section{Abstract}

Reception aesthetics is a literature theory constructed as a result of coming together some important approaches in reader-oriented theories. It approaches to literature through meaning. Hence, it also connects to the linguistic philosophy. Its most salient feature is to see reader as a central element in meaning/interpretation process. In this context, it highly ignores author and text itself. In this study, we examined Reception Theory with its three significant theorists and their assertions. They are Wolfgang Iser, Hans-Robert Jauss and Stanley Fish. Methodologically at first, we explain their arguments with examples and then, touch on their deficiencies and certain criticisms about them. We reach the result that Reception Theory is inadequate in both defining literature and solving the meaning problem.

*Yıldız Teknik Üniversitesi Sosyal Bilimler Enstitüsü, aylakmaylak@gmail.com 
Yet, we reveal that it brings a revolutionary innovation to the field of linguistic philosophy and literature theory by including reader to the interpretation process.

Keywords: Reception Theory, Reader-Oriented Theories, Wolfgang Iser, Hans-Robert Jauss, Stanley Fish.

\section{Giriş}

nsanoğlu Antik Yunan'dan bu yana sanat kavramı üzerine düşünmektedir. Onun

Tanımını yapmaya, buna bağlı olarak da işlevini saptamaya çalışmaktadır. Birkaç

bin yıllık bu uğraş sayesinde pek çok akım, kuram ve teori ortaya çıktı. Dilbilim ve

Estetik gibi iki önemli bilim dalının gelişimi de bu sürecin bir ürünü olarak değerlendirilebilir. Gelinen noktada her bakımdan tatmin edici bir tanıma ulaşabildiği söylenemese de bu çabaya dair literatürün ve sanat bilincinin epeyce genişlediği ve derinleştiği iddia edilebilir.

Sanatın tanımı söz konusu olduğunda dolaylı olarak onun işlevinden de bahsedilir. Çünkü dil pragmatik bir yapıdadır ve dolayısıyla onu kullanarak yapılacak her eylem belli ölçüde pragmatik özellikler taşır. Aslında bir şeyi tanımlamanın bile pragmatik dinamikler üzerine kurulu bir eylem olduğu düşünülünce dile karşı taşınılan faydacı beklentiler daha iyi anlaşılır. Öte yandan sanat kavramına yaklaşırken tanım ve işlev unsurlarını birbirinden ayırmaksızın ele alan düşünceler de mevcuttur. Larry Shinner (2013, s. 27) bu iki unsurun ayrı ayrı ele alınmalarını tarihsel nedenlerle açıklayarak doğruluğu üzerinde tartışır. Dolayısıyla, her hâlükarda, "Sanat nedir?" sorusu, "Sanat ne işe yarar?" sorusuyla yakın bir ilişki içerisindedir.

Sanatın genel geçer özelliklere sahip evrensel bir tanımı varsa bile bugün o tanıma ulaşılabilmiş değildir. Köken olarak "sanat" sözcüğü, aslen Arapça olup “yapılan iş, meslek" anlamına gelmektedir (Koç, 2009, s. 90). TDK'da, “Bir duygu, tasarı, güzellik vb.nin anlatımında kullanılan yöntemlerin tamamı veya bu anlatım sonucunda ortaya çıkan üstün yaratıcılık olarak tanımlanır. M. Orhan Okay sanatın yüzlerce tanımının yapılabileceğini söylemiş ve bunlardan birkaçına Sanat ve Edebiyat Yazıları'nda yer vermiştir (Okay, 1990). "Sanat, tabiatın taklididir.", "Sanat, ideal ve kusursuz güzelliğin aranmasıdır.", "Sanat, zihindeki bir tasavvuru ortaya koymak için gösterilen bir maharettir." gibi örneklerin yer aldığı bu tanımlar bilinen sanat kavramına daha fazla yaklaşan tanımlardır. Öte yandan günümüzde çok sık kullanılan bir tanım, sanatın okurda (izleyicide, dinleyicide) estetik yaşantı uyandıran insan üretimi eserler olduğunu söyler. Yukarıda verilen tanımların ortak bir özelliği var. İlki haricindeki (zaten sanat sözcüğünün köken anlamı bu makalenin ilgi alanına girmiyor) tanımların hepsi, tanımıyla beraber ya açık açık ya da dolaylı olarak sanatın işlevinden de bahseder. 
Sanatın estetik yaşantı uyandırması işlevinden bahseden tanımlama günümüzde pek çok edebiyatçı tarafından benimsenmiştir (Moran, 2014, s. 309). Çünkü diğer anlamları çatısı altında birleştirebilecek geniş bir tanım yelpazesine sahiptir. Öte yandan o da ne yeterince net ve açıktır ne de tanımlama arayışına son verecek denli güçlüdür. Arayışa son vermek şöyle dursun, yeni arayışların yolunu açmış, insanı daha derinde ve dolayısıyla daha zorlu bir maceranın içine itmiştir. Çünkü "estetik yaşantı" tabiri muğlaktır. Sanat felsefesi olarak da nitelenen Estetik, "güzellik bilimi" olarak tanımlanabilir (Kagan, 1982, s. 33). Bu durumda

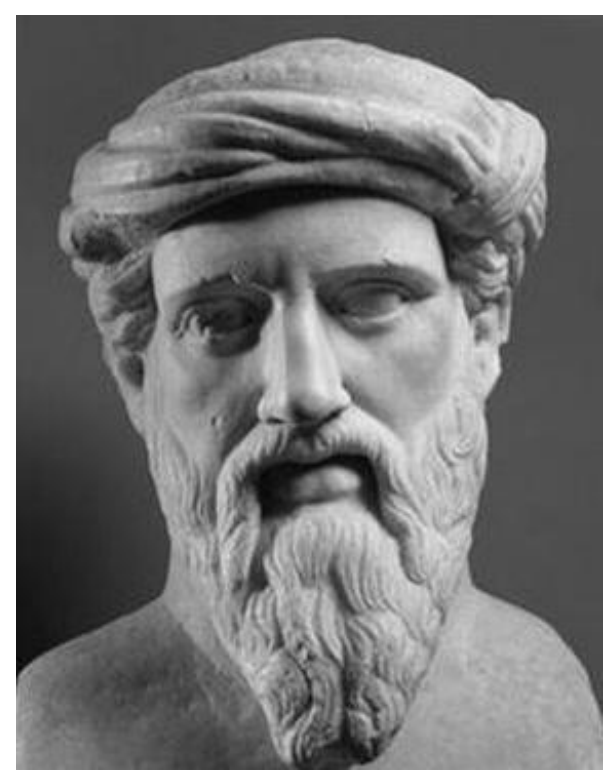

Pythgoros karşımıza güzel ve güzellik kavramları çıkar ki bütün muğlaklık bu iki kavramdan kaynaklanmaktadır.

Güzeli tanımlayabilmek, bir bakıma sanatı tanımlayabilmekten de zordur. Çünkü güzel, neredeyse tamamen öznel bir kavramdır. “Elma” ya da "taş" gibi doğadaki nesnelere göndermede bulunmaz. Bütünüyle soyuttur. Bir sıfat olarak nitelediği sözcüğe gerçek bir anlam katmaz. "Güzel masa" cümlesi, o masanın özellikleri hakkında bize herhangi bir nesnel bilgi vermez aslında. Masanın neden güzel olduğunu açıklamak gerekecektir. Fakat bu da yeterli olmaz çoğu zaman. Çünkü yapılan açıklamalar ile masanın güzel olması arasında kurulacak bir bağlantı yeterince nesnel olmayacaktır. Yani bu masaya, aynı özelliklerini dikkate alarak güzel denmesi, başka birinin onu güzel bulmasını garantilemez. Evrensel boyutta bir güzellik kavramı söz konusu değildir. Çünkü bu öznel değerlendirme insana özgü bir bilinçsel sonuçtur. Bir şeyin "güzel” olarak nitelenmesi, güzellik kavramına yüklenen anlamla doğrudan ilişkilidir. Bu kavramla ilgilenen bazı Antik Yunan filozoflarının kavramı algılamalarına ve ona dair yaptıkları tanımlara bakılacak olursa bahsedilen öznellik daha iyi anlaşılabilir. Örneğin, Pythgoros güzelliği, zıtlıkların harmanlanmasıyla oluşan denge olarak tanımlarken Herakleitos onu uyum, ahenk ve armoni olarak, Sokrates ise "iyi" olanla aynı şey olarak tanımlıyordu (Şimşek, 2014, s. 332).

Sanat da bu bağlamda güzel ile aynı yapıdadır. Doğada insandan başka sanat üreten hiçbir canlı yoktur. Dolayısıyla güzel kavramı ve bu kavramın üzerine kurulan estetik bilimi, karşılığı doğada bulunabilecek şeyler değillerdir. Estetik yaşantı uyandırma işlevini üstlenen sanat da aynı dertten muzdariptir o hâlde. Bu da yaşanılan tanımlama sıkıntısını belli oranda açılamaya yeter. 
Karşılığ1 doğada bulunamayan bu kavram için nereye bakılması gerektiği düşünülebilir o hâlde. Neyse ki cevap basittir: İnsan. Hem güzel kavramını hem de sanat olgusunu üreten insan, bunları açıklayabilecek tek varlıktır.

Sanatın bir kolu olan edebiyat için de aynı tarihsel süreç geçerlidir. "Edebiyat nedir?" sorusu, "sanat nedir?" sorusuyla ve bu soruya verilecek cevaplarla yakından ilişkilidir. Modern edebiyat kuramları ise bu soru bağlamında insana dört farklı açıdan yaklaşır:

1. Edebiyatı üreten, yani yazar

2. Edebiyatı tüketen, yani okur

3. Üretilen nesne, yani metin

4. Edebiyatın içinde üretildiği değerler sistemi, yani toplum (Moran, 2014: 10).

Elbette bu dört ayrı grup sıklıkla etkileşimde bulunurlar. Hiçbir kuram, bu dördünden salt bir tanesine yöneldiğini iddia edemez. Yazarı yüceltmesi bakımından birinci grubun en radikal kuramı sayabileceğimiz romantizm bile yazarı okurdan, metinden ya da toplumdan bağımsız düşünemez. Aynı şekilde Yapısalcılar ve Yeni Eleştiriciler de en basitinden metnin üzerine eğilen kendi varlıklarını yok sayarak metin incelemesi yapamazlar.

İçinde yaşadığımız postmodern çağda okur, diğer üç gruba göre daha ön plana çıkmıştır. Üretilen metinler okuru tüketici konumundan çıkarıp üretime katkı sağlamaya teşvik ederken yukarıda verilen sınıflandırma bile çatırdamaya başlamıştır. Yine de okur merkezli edebiyat kuramları, sanatın özünde bulunan öznelliğe en bariz vurguyu yapmalarından olsa gerek son birkaç on yılda daha rahat bir gelişme ortamı bulmuş, üreten ve tüketen olarak insan olgusu, nesne olarak da metin ve toplum iç içe geçmeye başlamıştır. Zamanın bile göreceli olduğunun ortaya çıktığı son yüzyılın ait olduğu medeniyet dairesinin edebiyata bu biçimde yansıması hiç de şaşırtıcı değildir.

Metnin anlamı sorununa eğilen bu dönem kuramları içinde belki de en dikkat çekici olanı Alımlama Kuramı'dır. Okurun, edilgen yapısından çıkartılıp etken bir konuma yerleştirildiği, anlamın ve estetiğin okurdan başka hiçbir yerde aranmadığ bu kuram postmodernizmin erken dönem habercilerinden biridir. Bu makalede Alımlama Estetiği olarak anılan bu edebiyat kuramı incelenecek, barındırdığ eleştirilere değinilecek ve son olarak bir metin üzerinde uygulamasını yapılacaktır.

\section{Alımlama Estetiği Nedir?}

Pozitivizmin çöküşünün akabinde hemen her alanda olduğu gibi edebiyatta da geleneksel kurallar bir çözülme sürecine girdi. Siyasi dünyadaki demokrasi kültürü, öznelci akımların ön plana çıkmaya başlamaları gibi toplum yaşamındaki radikal değişimler klasik anlayışların edebiyata bakışta yetersiz kalmasına neden oldu. Her şey hızla değişti, peş peşe iki kuşak arasında bile büyük algı farkları meydana geldi. İki büyük dünya savaşı, atom 


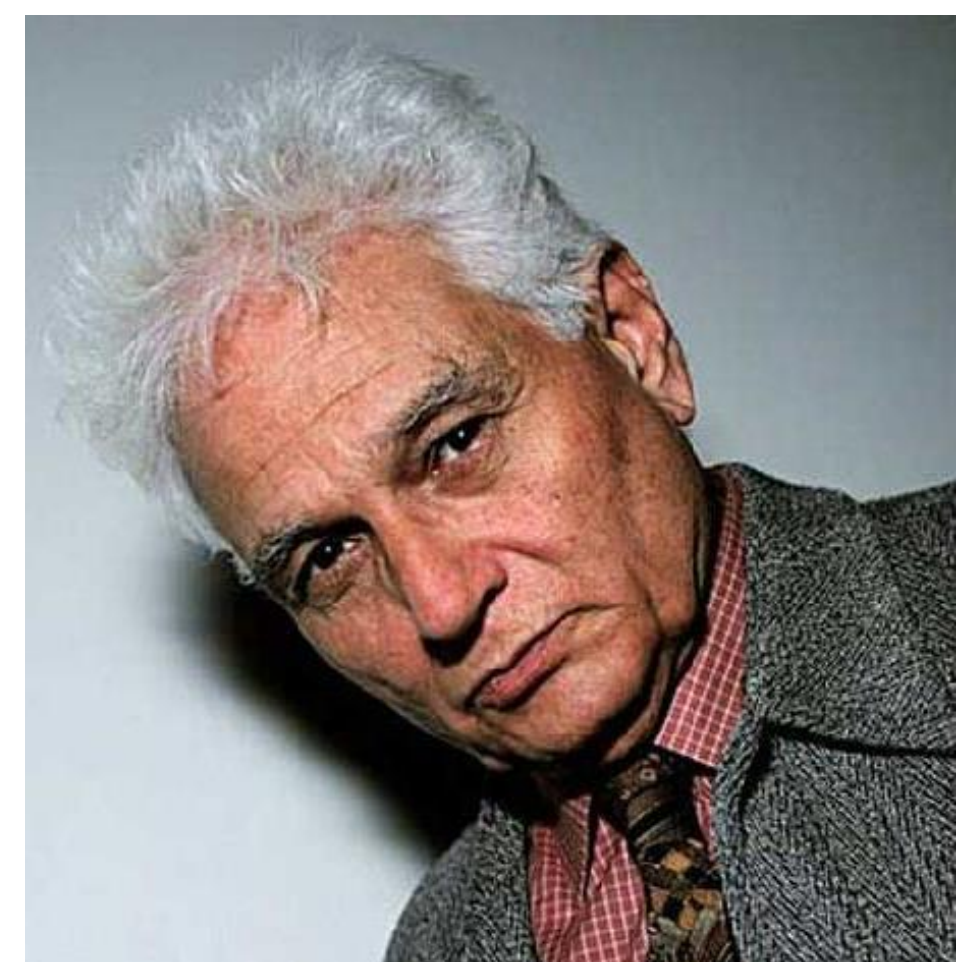

Derrida bombası, soykırımlar, aya ilk kez ayak basılması gibi yüz sene öncesinde hayal dahi edilemeyecek şeyler birbiri ardına, henüz ötekini tam anlamiyla sindiremeden vuku buldu. Yönünü ilerlemeye, saf bir gelişimciliğe çevirmiş olan bir çă̆, Modernizm çağı böylece hayatımıza girmiş oldu. Kapitalizmle beslenen bir çağdı bu kuşkusuz ama antikapitalist akımları da bünyesinde barındırıyordu. Şehirler büyüyor ve insan hayatının ekseninde git gide daha fazla yer kapliyordu ama kırsal kesim yaşantısına da bazı

önemli roller bahşedilmişti. Modernizm, büyük kitlesel hareketlerin, soğuk savaşın çatısı altında sınırları kesin olarak çizilmiş türlü kutuplaşmaların dönemiydi. Her topluluk kendini bir bütün hâlinde duyumsuyor, kendi anlayışını bünyesindeki tüm bireysel anlayışlardan üstün tutuyordu. Modernizmin kapitalist akımları da anti-kapitalist akımları da tek seslilik ve tek anlamlılıktan ötesine tahammül göstermiyordu. Ne var ki birey, yukarıdan dayatılan bu tek sesliliğe karşı çıkmak için karşıt kutba geçmekten başka yollar da olabileceğini keşfetti (Ecevit, 2004, s. 40-47).

Bu durum, birey sayısı oranında farklı algılama sayısı anlamına geliyordu. Artık tek anlamlılık bu yeni nesil için hiçbir şey ifade etmiyordu. Modernizmin tek anlamlılığı bu bağlamda postmodernizmde çok anlamlılığa dönüştü (Ecevit, 2004, s. 68). Edebiyat dünyasında bu çok anlamlılı̆̆ın yalnızca yazara mahsus olamayacağı düşüncesi çok hızlı kavrandı. Postmodern yazar, modernizmin dayattığı tek anlamlılığı kıran, kendi anlamlarını yaratan kişiydi. Fakat yarattığı anlamın da tek bir anlama sahip olması beklenemezdi artık. Yazarın ve metnin tekilliği karşısında okur denilen kalabalık bir kitlenin çoğulculuğu devreye giriyordu. Artık anlam ne yalnızca yazarda ne de yalnızca metinde aranıp bulunacak bir şey olmaktan çıkmıştı (Moran, 2014, s. 240-241).

Bu noktada yapısalcılık ve postyapısalcılık gibi daha dolaylı yaklaşımlar olduğu gibi postmodern edebiyata okuru merkez alarak en fazla yaklaşan eleştiri akımı Alımlama Estetiği olmuştur. Berna Moran, Alımlama Estetiği'nin tanımını şöyle yapıyor: “1960’ların sonundan bu yana edebiyat eserlerinin anlamı ve yorumu ile ilgili olarak okurun işlevini inceleyen çeşitli kuramlara verilen genel bir addır" (Moran, 2014: 240). Bu bağlamda 
Alımlama Estetiği'nin sanatın tanımıyla uğraşmadığını, anlam üzerinde yoğunlaştığını ve anlamın yazarda $\mathrm{m}$ eserde mi yoksa okurda mı ortaya çıktığını sorguladığını görürüz. Aslında Alımlama Estetiği, bu sorgulamada okurdan yana net bir tavır koyar. "Zira okur olmadan edebiyat metinleri de olamaz (...) Edebiyatın var olabilmesi için okur da yazar kadar hayati önem taşır." (Eagleton, 2014: 87)

Edebiyatın bu yapısı, dilin yapısıyla doğrudan ilişkilidir. Saussure'ün ve bilhassa Derrida'nın ortaya koyduğu şekliyle dil, mutlak bir anlama sahip olması mümkün olmayan göstergelerden oluşan bir sistemdir ${ }^{1}$. Edebiyat da dil üzerine kurulu bir sanat dalı olduğu için mutlak bir anlama sahip olamazdı. Ne var ki edebiyat eserlerinin "anlamsız" olduğu manasına da gelmez bu. Suç ve Ceza herkeste farklı duygular uyandırmış olabilir ama olay örgüsünü farklı bir şekilde "anlamış" bir okurdan bahsetmek pek de doğru olmayacaktır. Anlam mutlak değil, fakat yine de bir anlam var: İşte Alımlama Estetiği tam bu noktaya, anlamın oluştuğu ana odaklanır. Umberto Eco, bu yaklaşımı şöyle tanımlıyor:

“Herhangi bir metnin (dilsel olmayan bir metin de olabilir) işleyişi, üretilme anının yanı sıra (ya da üretilme anı yerine) bu metnin anlaşılması, gerçekleşmesi, yorumlanması açısından hem alıcısının (gönderilen) oynadı̆̆ı rol, hem de metnin bu tür katılım biçimlerini nasıl öngördüğü göz önüne alındığında açıklanabilir." (1991: 16-17)

Romantizmden beslenen Duygusal Etki Kuramı ile Alımlama Estetiği bu bağlamda birbirlerinden ayrılıyor. Duygusal Etki Kuramı, yazarın metne bilinçli olarak kattığı, okurda uyandırılması beklenen duyguları/psikolojik etkileri merkez alarak okuru değerlendirir (Moran, 2014: 240). Her şeyden önce okuru pasif bir konumda tutması ile Alımlama'dan bariz biçimde ayrılır. Alımlama Estetiği'nin konusu duygusal değil, düşünsel ve bilgiseldir. Yani önemli olan, bir edebî eserin size yaşattı̆̆ı duygular değil, sizin onun anlamını oluşturma yönünde yaptığınız katkıdır.

Dilin yukarıda bahsedilen mutlak olamama özelliğinden ötürü edebî metinlerde de anlam tam olarak oluşmaz. "Alımlama Estetiği kuramına göre her yazınsal ürün birçok belirsizlikler, boşluklar içerir, okuma sürecinde soru işaretleri ortaya çıkarır" (Özbek, 2013: 16). İşte okur, okuma sürecinde bu boşlukları doldurarak anlamın oluşmasına katkı sağlar. Okurun buradaki katkısını nitelik ve beklenti yönleriyle açıklamaya çalışan belli başlı üç kuramcı vardır. Bunlar Konstanz Ekolü'nü temsil eden Wolfgang Iser ve Hans-Robert Jauss ile ABD'li Stanley Fish'tir. Alımlama Estetiği'ni daha iyi anlayabilmek için bu üç kuramcıyla ve onların kuramlarıyla devam etmek gerekir.

\footnotetext{
${ }^{1}$ Bkz. Yapısalcılık ve Postyapısalcılık Kuramları.
} 


\subsection{Wolfgang Iser ve metnin iki ucu}

22 Temmuz 1926 tarihinde Almanya'da doğan Wolfgang Iser, 24 Ocak 2007 senesinde ölmüştür. Hans Robert Jauss ile beraber Konstanz Edebiyat Ekolü'nün kurucularındandır. İkinci Dünya Savaşı'ndan sonra Leipzig Üniversitesi, Tübingen Üniversitesi ve Heidelberg Üniversitesi'nde İngilizce, Almanca ve Felsefe üzerine çalışmalar yapmıştır (Shi, 2013: 982).

Alımlama Estetiği (Rezenptionsasthetik)

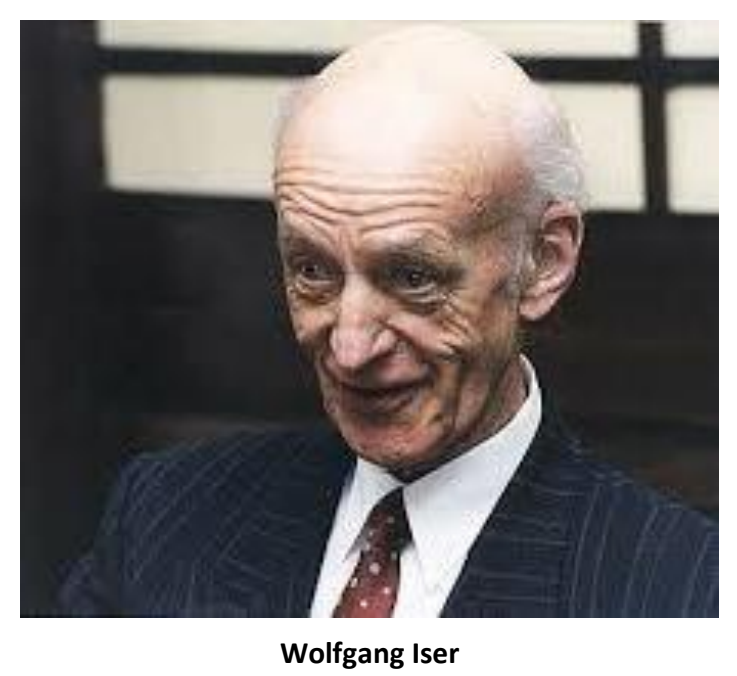
kuramını, artistik ve estetik olmak üzere iki uç üzerine kuruyor Iser (Moran, 2014: 242). Bu bağlamda artistik uç, yazarın yarattığı metni ve estetik uç da okurun yaptığı somutlamayı temsil ediyor. Iser, "bu iki uç olmadan yapıtı meydana gelmiş saymıyor. Başka şekilde söylersek, yapıta bir nesne gibi değil, bir olay gibi bakılıyor. Metinle okur arasındaki alışverişten doğan bir olay" (Moran, 2014: 242).

Iser'in 1972 yılında yayımlanan The Implied Reader (İma Edilen Okur) ve 1978 y1lında yayımlanan The Act of Reading (Okuma Eylemi) adlı kitapları (Deneau, 1980: 76), onun kuramının dayanaklarını oluşturur. Roman Ingarden'ın “önanlamalar” (Eagleton, 2014: 90) kuramından aldığı referanslarla yola çıkan Iser, yazar-okur uyumunun sağlanması ve bu sayede metnin oluşması için bazı ön koşullar ortaya koyar. Bu ön koşullardan en açı ve en kolay kabul edilebilir olanı, edebiyat bağlamında dilin, roman bağlamında ise yazı dilinin hem yazar için hem de okur için önceden biliniyor olması gerektiğidir. Daha özel bir ifadeyle bu, metni oluşturan teknik unsurların ve stratejilerin alımlayıcı tarafından ön-bilinmesi anlamına gelir (Eagleton, 2014: 90). Uzlaşımsal bir teoridir bu; yazarla okur arasındaki uzlaşmayı şart koşar. Antik çağlardan kalma dili çözülememiş metinleri düşünecek olursak bu uzlaşmanın gerekliliğini anlayabiliriz. Bu metinler bizim için, bir çocuğun rastgele bir şeyler çiziktirmesinden çok da farklı değildir. Belki tespit edilebilir bir düzenle sıralanmış bazı sembolleri, bu sembollerin bir araya gelişlerini ve bazılarının aralarındaki boşlukları seçebiliriz ama bu sembollerin anlamını çözemediğimiz sürece aslında bunların bir anlamları olup olmadığı konusunda bile bilgisiz durumdayızdır. Iser'e göre böyle bir metin, meydana gelmiş sayılamaz. Çünkü okurun metne hiçbir etkisi yoktur, bu hâlde yazarın metne bir etkisi olup olmadığı önemsiz kalır.

Bu açık ve kolay kabul edilebilir ön şart, günümüz edebiyat dünyası için çok da işlevsel değildir. Zaten Iser de bu kadarla yetinmez. Dil ve sembolden öte bir edebî metin içerisinde, metni oluşturan teknik unsurlar, dilsel çağrışımlar yazın stratejileri gibi faktörler 
de bulunur. "Oku da baban gibi eşek olma" tümcesinin klasikleşmiş alımlama sorunu teknik bir yazı dili unsurundan, virgülün konulacağı yerden kaynaklanır. "Baban gibi” kısmından sonra konacak virgül ile "oku da" kısmından sonra konacak virgül cümleye apayrı iki anlam kazandırır. Yazar bu anlamı vermekle, okur da virgülün bu işlevini bilmekle yükümlüdür.

Fakat Iser'in teorisini asıl ilgi çekici kılan, dilsel ve teknik ön-bilmelerden çok anlamsal ön-bilmelerin gerekliliğidir. Her metin boş alanlar ve belirsizlikler barındırır. Çünkü "Iser'e göre metinde yazar her şeyi söyleyemez ve ister istemez birtakım yerlerin doldurulması okura düşer" (Moran, 2014: 242). Şöyle bir cümle gördüğümüzde; “Dışarı çıkmadan önce montunu giydi, önünü sımsıkı kapattı", soğuk havayla ilgili çağrışımları kendi kendimize yaparız. Yazarın bu cümlenin sonuna "çünkü hava soğuktu" biçiminde bir cümle eklemesi gerekmez. Mont giymek ve dahası montu iyice kapatmak, yazarın ve okurun ortak bir bilinç durumuna, soğuk hava olgusuna gönderme yapar. Böyle bir bilinç durumuna sahip olmayan okur, varsayımsal olarak, roman kişisinin neden mont giydiğini bilmeyecek, yazarın daha açık bir yönlendirmesine ihtiyaç duyacaktır. Böyle bir durumda Iser'e göre metin tamamlanmış sayılmaz.

Ne var ki Iser, okuyucuyu tek yargı sahibi de yapmaz. Üstteki örnekte mont-soğuk hava bağlantısını kuramayan okur için yazarı suçlu bulmaz. Çünkü okur, metni alımlarken tamamen özgür değildir. Onun görevi, yazarın bıraktığı belirsizlik alanlarını doldurmaktır. Eğer yukarıdaki örnek cümle metnin içinde gerçekten de bir soğuk hava bağlantısını gerektiriyorsa okur bu bağlantıdan mutlaka haberdar olmalıdır. Tutup da bu cümleyi havanın sıcak olmasına ya da daha makul bir örnekle, salt moda kaygılarına bağlayamaz. Okur, yazar tarafından yönlendirilmeye açık, metnin talep ettiği ön-bilme durumlarına sahip olmalıdır. Yani her metin, kendi okuyucusunu "ima eder". "Her edebî metin potansiyel okurlarını dikkate alarak inşa edilir, kimin için yazıldığına dair bir imge içerir" (Eagleton, 2014: 96).

O hâlde her metin tek, belli bir anlamı mı gerektirmektedir? Iser bunu da kabul etmez. Her metinden birden fazla anlam çıkarılabileceğini, metni açıklamak için tek bir doğru yorum olamayacağını, "farklı okurlar[ın] eseri farklı şekillerde gerçekleştirmekte özgür" (Eagleton, 2014: 93) olduklarını söyler. Yani bir bakıma, mont giyip önünü sımsıkı kapatmak için havanın ne kadar soğuk olması gerektiğini hesaplamakta ya da en soğuk havalarda bile dışarı bir ceketle çıkan okur için roman kişisinin biraz hassas olduğunu düşünmekte sakınca yoktur. Bu tarz "alımlamalar" metnin bütünlüğünü bozmaz, onun ön-gerektirdiği şartları sağlayan bir okur tarafından alımlandığı için "artistik uç"a da "estetik uç"a da zarar vermez.

Metnin gerçekliği ve başarısı, temelde buna benzer bir sürecin nihayetinde gerçekleşir. Elbette edebî bir eserde gerçeklik, mont ve soğuk hava arasındaki basit bağlantıda aranmaz. Iser'e göre "kurmaca metnin gerçekle ilişkisi ideoloji yönündedir" (Moran, 2014: 243). Yani, 
metnin içindeki kurmaca ögeleri gerçek dişı bir evrende var olsalar da bu evreni şekillendiren maddi ve manevi koşullar gerçek hayattan ithal edilir. Kurmaca metnin toplumla ve medeniyetle bağlantısı yalnızca burada aranmalıdır. Ne var ki toplumun ve medeniyetin sahip olduğu bu değerler her zaman sabit kalmazlar. Doğadaki her şey gibi onlar da zaman içinde değişmeye, başka yeni değerlere dönüşmeye mahkûmdurlar. Bu da metnin nesnelliğini imkânsız kılan bir diğer faktördür. Farklı dönemlerin okurları aynı metinden çok farklı yaşantılar çıkarabilir.

Metnin ideolojiyle olan bu bağlantısı işbirlikçi bir bağlantı değildir (Moran, 2014: 243). Edebî metin kendi döneminin eleştirisini yapmalıdır. Iser'e göre yazar, içinde bulunduğu değerler sistemini tartmalı, geçerliliklerini sorgulamalı, onun ister istemez eksik ve yetersiz bıraktığı durumlara ve olgulara parmak basmalıdır (Moran, 2014: 243-244). Bu yüzden okur da "okurken esnek ve açık fikirli, kendi inançlarını sorgulamaya hazır" olmalı, bu inançların dönüştürülmesine de izin vermelidir (Eagleton, 2014: 92).

Metnin estetik başarısı ise okura yaşattığı estetik yaşantıdan kaynaklanır. Iser'in kuramına göre bu estetik yaşantı, okurun metnin içindeki bilinmezlikleri bilinir kılmasıyla, boşlukları doldurmasıyla, yani metnin oluşumuna sağladığı katkıyla gerçekleşir. “Okurun kendi çabasıyla anlamı bütünlemesi ve keşfetmesi bir çeşit estetik zevk sağlar ona" (Moran, 2014: 244). Bilimsel metinlerin estetik olarak değerlendirilmemesinin nedeni budur. Çünkü bilimsel metinler, anlamı mümkün olduğunca hazır bir biçimde okura sunmaya gayret ederler. Böylece okur, salt tüketici konumuna geçer. Metnin üretimine katılamadığı için estetik bir yaşantı da duymaz.

\subsubsection{Wolfgang Iser'in kuramına getirilebilecek eleştiriler}

Wolfgang Iser'in edebiyat anlayışı okura büyük önem gösterse de salt okur merkezli bir kuram olarak görülemez. Çünkü okura gelmeden önce metne ve yazara öncül bir pay verir. Kuram dikkatle incelendiğinde, metindeki anlamı gerçekleştirenin gerçekten de okur olduğu ama o anlamı kuranın yazar, toplum ve dilsel ögeler olduğu görülür. $\mathrm{O}$ hâlde bu kuram, "okur merkezli" olmaktan çok okurun işlevini açıklayan bir kuramdır. Edebiyat eleştirisine getirdiği en büyük yenilik, birden fazla anlamı mümkün kılması ve bunu okur üzerinden yapmasıdır.

Iser'e belki de en büyük eleştiriyi Terry Eagleton yapar. Kuramın getirdiği yenilikleri ve ortaya koyduğu ilkeleri uzun uzadıya açıklayan ve gerektiği yerlerde onu alkışlayan Eagleton, iş metnin okurdan ön-beklediklerine gelince kaşlarını çatar. Iser'in kuramını "liberal hümanist bir ideolojiye dayalı" olmakla itham eden (Eagleton, 2014: 92) İngiliz eleştirmen, Iser'in okura tanıdığı özgürlük alanını eleştirir. Kuramın okurdan beklediği ideolojisiz olma durumunu başlı başına bir ideoloji olarak niteler. Böyle bir okurun esere 
yapacağı katkı üzerine düşünmemizi ister. Dahası, Iser'in "belirsizlikleri normalleştirme" tabirini çok sesliliğe aykırı bulur. Marksist bir dünya görüşüne sahip olan Eagleton'ın eleştirilerinin böyle ideolojik referanslar barındırması çok da şaşırtıcı değildir.

Iser'in, okura havale edilmiş de olsa bir nesnellik kaygısı taşıdığı, diğer kuramların yaptığı gibi yazarı ya da eseri değil de okuru sınırlandırmaya kalktığı söylenebilir. Bu durum, yorum olgusunu bilimsellik kılıfına sokma gayreti olarak adlandırılabilir. Iser öngereklilik iddiasıyla ya da "ima edilen okur" teorisiyle öznelciliği ve bir bakıma okura dönüklüğü kısıtlar. Diğer bir alımlama kuramcısı olan Stanley Fish, Iser'in bu yaklaşımını eleştirir (Eagleton, 2014: 98). Anlamın metnin içinde "gücül" (Moran, 2014: 246) bir hâlde de olsa bulunuyor olmasının nesnel referansları gerekli kıldığını, bu durumun da okurun “alımlama" sını kısıtladığını söylemek pek yanlış olmayacaktır.

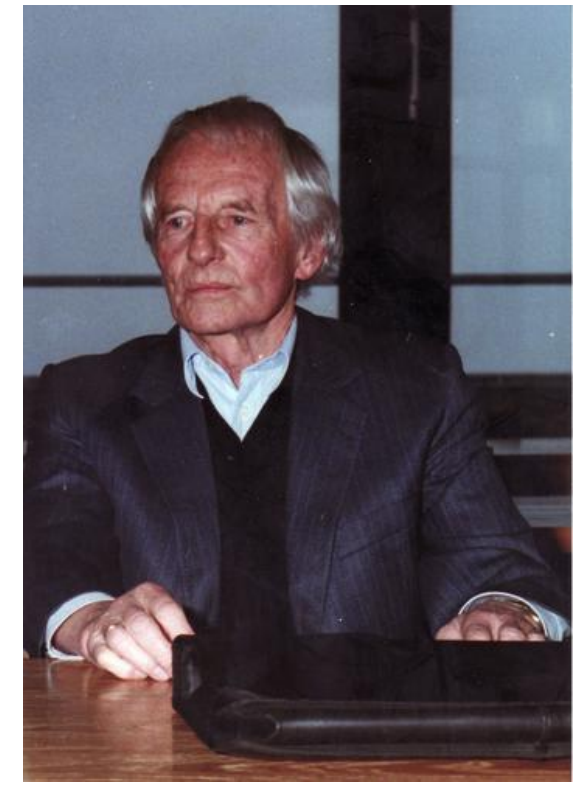

Hans-Robert Jauss

\subsection{Hans-Robert Jauss ve beklentiler ufku}

Wolfgang Iser ile birlikte Konstanz Ekolü'nü kuran Hans Robert Jauss, 1921 yılında Göppingen, Almanya'da doğmuştur ve ölüm tarihi 1997'dir (Oxford University Press, 2016). 1982'de yayımlanan Toward an Aesthetics of Reception (Bir Alımlama Estetiği'ne Doğru) ve Aetshetic Experience and Literary Hermeneutics (Estetik Deneyim ve Edebî Yorumlamalar) adlı eserleriyle kendi kuramını ortaya koymuştur.

Jauss da Iser gibi edebî metinlerin yorumlanmasında okuru ön plana çıkartır. Fakat Jauss'un başlıca dinamiği tarihtir. Okurun edebiyattaki rolünü açılayabilmek için edebiyat tarihine yeni bir gözle bakar. Konstanz Üniversitesi'ndeki ilk çalışmasının başlığı, "Literary History as a Challenge to Literary Theory" (Edebiyat Kuramı'na Karşı Edebiyat Tarihi)'dir (Buchanan, 2010: 281). Iser tarihsel etkiyi edebî metnin gerçekliğini sorgularken ele almıştı ama Jauss bu etkinin alanını genişletir. Edebiyat tarihinin, okurların tepkisine göre yazılması gerektiğini düşünür (Moran, 2014: 246). Çünkü okur, ait olduğu dönem tarafından sınırları belirlenen entelektüel bir pencereden bakar edebî eserlere. Bu sınırlar dönemden döneme değişiklik gösterdiği için edebî eserlerin yorumlanması ya da daha doğru bir tabirle alımlanması da değişiklik gösterir. Aslında değişen şey eserin yorumlanması değil, eseri çevreleyen edebî gelenektir. Okurda beliren bu dönemsel/tarihsel etkiye Jauss "beklentiler ufku" (envartungs-horizont) (Thiselton, 2006: 293) ismini verir. 
Beklentiler ufku, okurun bir edebî eserden tarihsel, toplumsal, kültürel olarak bir ön beklenti içinde olması durumudur. Böylece okur tarihsel bir bağlama yerleştirilir. Jauss'un okur-merkezciliği, edebiyatın, tarihsel bağlamına yerleştirilmiş bu okur teorisinin üstüne kurulmasını gerektirdiği için diğer okur merkezli kuramlardan farklıdır. Jauss'un çalışmasının amacı, “yazarlar, etkiler, edebî eğilimler üzerinde değil, çeşitli tarihsel 'alımlama' uğraklarına göre tanımlanan ve yorumlanan edebiyat üzerinde odaklanan yeni bir tür edebiyat tarihi üretmektir" (Eagleton, 2014: 96).

İçinde bulunduğu dönemin belirlediği beklentiler ufkuyla metne yaklaşan okur, bu beklentilerin karşılanması ölçüsünde estetik bir yaşantı edinir. Eleştirmenin görevi, farklı dönemlerdeki beklentiler ufku yelpazelerini tespit etmek ve metinleri, ait oldukları dönemin beklentiler ufku yelpazesine göre okumaktır. Ancak bu sayede farklı dönemlerdeki okurların metne gösterecekleri tepkileri anlayabiliriz (Moran, 2014: 246-247). Metnin edebî değeri de bu okurların alımlamalarından yola çıkılarak belirlenebilir.

Yazar ve eser bu yaklaşımla edilgen bir konuma yerleştirilir. Metnin anlamı ve gerçekliği okurun tüketim sürecinde ortaya çıar. Okur ise dönemin şartlarınca şekillendiği için edilgen, bu şartları öznel yorumlarıyla ve kendi alımlamasıyla yansıttığı için etken/belirleyici bir konumdadır. Jauss'un önerdiği edebiyat tarihi anlayışı bu bağlamda devrimsel niteliktedir. Çünkü edebî metinleri, dâhil oldukları akımlar, yazarının dünya görüşü, diğer metinlerle kıyaslanmaları gibi değişkenler yerine akranı olan okurların o metne bakışları bağlamında incelenirse ortaya bambaşka bir edebiyat tarihi çıkacaktır.

Jauss'un kuramı bazı yönlerden Alman filozof Hans-Georg Gadamer'in yorum bilgisi kuramına benzer. Gadamer, anlamın yorumlama esnasında ortaya çıktığını ileri sürer (Tatar, 2001: 288). Fakat bu yorumlama süreci öznel ya da özgür bir süreç değildir. Genelde anlam ve anlamak kavramları üzerinde duran Gadamer, bu ikisine önyargılar yoluyla ulaşır. Bir bakıma Iser'in ön-gereklilik kuramını hatırlatan bu tabir, Iser'den farklı olarak tarihsel referanslara sahiptir. Tarihin ya da geleneğin geçmişten bugüne taşıdığı bilinç durumu, anlama esnasında kişide kaçınılmaz önyargılar oluşmasına sebep olur. Bu önyargıların yarattığı ufukla nesneden gelen anlam birleştiğinde yorum ortaya çıkar. Bu üç öge birbirlerini dönüştürerek, tamamıla tarihsel temellerin üzerine yeni eklemeler yaparak yeni bir bilinç düzeyini meydana getirir. Böylece öznenin ufku, geleneğin ufkuyla birleşerek nesneye bakar; Gadamer'in "ufukların kaynaşması" diye tabir ettiği bu durum, yorum olgusunu doğurur (Tatar, 2001: 294).

“Ufukların kaynaşması", tarihten gelerek bugüne etki eder. Jauss'un "beklentiler ufku” ise bugünden yola çıkarak tarihi anlamaya çalışır. O hâlde kesiştikleri en belirgin nokta tarihe verdikleri önemdir. Fakat okura ya da yorum öznesine verdikleri önem söz konusu olduğunda birbirlerinden ayrılırlar. Gadamer nesnel bir anlamın varlığını savlar (Tatar, 2001: 
288-289). Bu anlam mutlaktır ama sahip olduğumuz yöntemlerle ulaşamayacağımız bir konumdadır. Yorumlar, bu anlamın türevleridirler, yanlış değillerdir ama asla tam olarak gerçek bilgiye (hakikate) ulaşamayacaklardır. Jauss ise nesnel anlamın peşine düşmez. Böyle bir anlamın varlığına inanıyormuş gibi değildir. Jauss geleneğin devamlı dönüştüğünü, yenilendiğini, bunu gerçekleştirenin de yorumun ta kendisi olduğunu ileri sürer. Yani anlam öznel değildir ama mutlak bir nesnelliğe de sahip olamaz. Onun farklı dönemlerde sahip olduğu farklı anlamların birleşmesi, bizim edebiyat tarihi dediğimiz olguyu meydana getirir.

Jauss, beklentiler ufkunu tarihsel bağlamında değerlendirirken geleneğin dönüşümlerine de açıklık getirir. "Şöyle ki, yenilik getiren yani beklentilere uymayan bir eser o dönemin okurlarına yeni bir ufuk açar ve estetik ölçütlerin değişmesine neden olur" (Moran, 2014: 247). Böylece gelenek değişir, yeni beklentiler ufku ortaya çıkar. Bundan sonra yazılacak eserler bu ufka uyum sağladığı, onun beklentilerini karşıladığı sürece ve yalnızca o dönem için başarılı bir eserdir. Daha önceki geleneğin sınırlarında kalmış bir eser gerici kabul edilir. $\mathrm{O}$ hâlde yeni bir geleneği vaat eden, geleneği dönüştürme potansiyeli taşıyan eserler de çağından ileride olan eserlerdir (Moran, 2014: 247). Bu son gruba dâhil olanlar, genelde üretildikleri dönemin içerisinde anlaşılmazlar. Fakat katkı sağladıkları biçimde gelenek dönüşünce hak ettikleri başarı konumuna oturtulurlar. Türk edebiyatı tarihinde bu duruma en belirgin örnek, Oğuz Atay'ın Tutunamayanlar romanı olsa gerektir.

\subsubsection{Hans-Robert Jauss' un kuramına getirilebilecek eleştiriler}

Jauss'un kuramı da estetiğe bir sınır çizmeye yeterli değildir. Zaten temelde böyle bir vaatte de bulunmaz. Dikkatle incelendiğinde kuramın içerisinde "Estetik nedir?" ya da "Güzel nedir?" gibi sorulara hatta "Edebiyat nedir?" sorusuna bile sağlam bir cevap bulamayız. Muhtemelen ilk iki soruya, "farklı tarihsel dönemlerde meydana gelen farklı sosyal geleneklerin, bünyesinde yaşayan insanlarca özümsenip sanat eserine yönlendirilmesiyle ortaya çıkan öznel yorumların incelenmesiyle elde edilen ve yalnızca o gelenek içinde geçerli olan soyut değer yargılarıdır" biçiminde bir cevap verilebilir. İkinci soru da bu bağlamda cevaplandırılabilir belki ama bu cevap "edebiyat nedir?" sorusundan çok "edebiyat tarihi nedir?" sorusunu karşılamaya yetecektir.

Jauss'a getirilebilecek bir diğer eleştiri, tarihi Hegelci bir mantıkla düz bir çizgi gibi algılaması yönünde olabilir. Tarih, bazı belli genellemelere müsait olsa da asla tek boyutlu, çizgisel bir olgu değildir. Her tarihsel dönem, tüm diğer dönemlerle grift bir ilişki içerisindedir. O yüzden tarihi dönemlere ayırmak hem zordur hem de pratik sonuçlarından başka pek bir işe yaramaz. Jauss'un edebiyat tarihi anlayışı bu bağlamda sakat bir anlayıştır. Merkeze okuru ya da özneyi oturtuyor; bu sayede bu girift yapıya yaklaşmayı umuyorsa bile bu, sorunu çözmekten ziyade daha farklı sorunların doğmasına neden olacaktır. 
Doğacak olan bu sorunlar, Jauss'un beklentiler ufku kuramıyla ilgilidir. Berna Moran bu konuda şunları söyler: “... Jauss'un hesaba katmadığı bir ufuk çeşitliliği söz konusudur. Aynı dönemde tüm okurların katıldığı bir beklentiler yelpazesi olduğunu söyleyemeyiz. Okurlar farklı gruplardan oluşabilir ve her grubun kendi beklentiler ufkunu hesaba katmak gerekir" (Moran, 2014: 248). Böyle bir yaklaşımla yazılacak bir edebiyat tarihi asla tam ve kusursuz olamaz.

\subsection{Stanley Fish ve eylem olarak anlam}

Stanley Eugene Fish 1938 yılında Providence, ABD'de doğmuştur. Pennsylvania Üniversitesi'nde ve daha sonra Yale Üniversitesi'nde eğitimini tamamlamış, akademik kariyerini California Üniversitesi'nde, Johns Hopkins Üniversitesi'nde, Duke Üniversitesi'nde, Illinois Üniversitesi'nde ve Florida International Üniversitesi'nde tamamlamıştır (Encyclopædia Brittanica,

2016). Bu makalenin yazıldığ

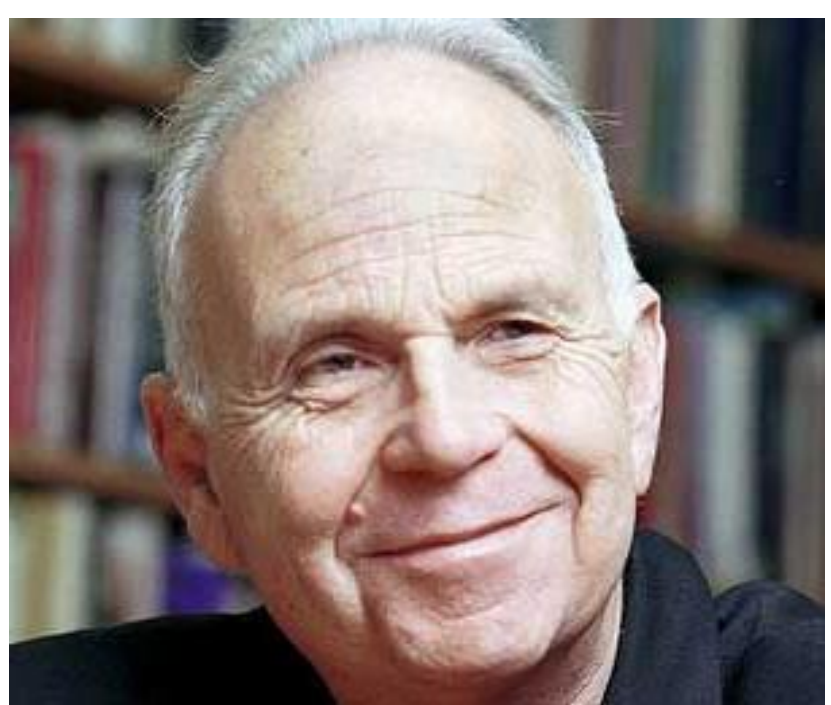

Stanley Fish yaşında olan Fish yaşamını ABD'de sürdürmektedir.

Okur merkezli kuramlar içinde okura en büyük rolü Fish'in kuramı verir. Iser'in, Jauss'un ve onların öncüllerinin aksine Fish, anlamı aramak için okur üzerinden tarihsel ya da metinsel bağlamlara başvurmaz. Tek dayanağı okurdur. Fakat her şey bu kadar basit de değildir aslında. Fish okur üzerinden farklı bağlamlara sıçramaz ama bunu anlam üzerinden yapar. Ortaya koyduğu en büyük yenilik de budur. Onun kast ettiği anlam olgusuyla Iser'in ya da Jauss'un kast ettikleri çok farklıdır.

Iser'e göre anlam, metnin içinde potansiyel olarak vardı. Okurun görevi onu ortaya çıkarmaktı. Jauss'a göre ise anlamı oluşturan şey farklı dönemlerin okurda oluşturduğu beklentiler ufkuydu. Fakat Fish anlamı oluşturanın yalnızca okur olduğunu söyler. Bu anlam, metnin kendisinden, yazarın niyetinden, dil ögelerinden ve tüm diğer edebî etkenlerden bağımsız olarak ortaya çıkar. Onu oluşturan şey bu ögeler değil, okurun okuma eylemidir. Bu eylem esnasında okur, kendi yaşantısını metinle birleştirerek anlamın oluşmasını sağlar. "Başka bir deyişle, bir sözcüğün, imgenin ya da herhangi bir ögenin metnin içinde (belli bir bağlamda) gördüğü işi belirlemek ona anlamını vermektir ve dediğimiz gibi, bu, ancak okurda uyandırdığı yaşantıya bağlıdır" (Moran, 2014: 98). 
Yani yalnızca anlam değil, dilsel ögeler de okurun eylemiyle gerçeklik kazanır. Onları birleştiren okurdur. Bu, İngilizcenin bir anlam ifade edebilmesi için muhatabı tarafından biliniyor olması gerçeğini ortaya koyar. Öte yandan İngilizce bilmeyen birine okutulan İngilizce bir metin bile okurda bazı yorum bilgisel süreçlere sebep olacaktır. "Define war " (İng. "savaşı tanımlamak") cümlesini gören ve bunu yazarın niyetiyle hiç alakalı olmayan bir biçimde alımlayan okur, en basitinden R.L. Stevenson'un Define Adası romanını hatırlayıp, zihninde bu romanla ya da bu romanı okuma süreciyle ilgili güzel bir anısını canlandırabilir. Bu durumda, Fish'in kuramına göre, anlam başarılı bir biçimde sağlanmıştır. Elbette bu, uç bir örnektir, kuramın işlevsel tarafı, edebiyatı tanımlamaya ve bir eleştiri biçimi geliştirmeye yöneliktir.

“Fish'e göre okuma, metnin ne anlama geldiğini keşfetme meselesi değil, metnin size yaptıklarını deneyimleme sürecidir" (Eagleton, 2014: 248). O hâlde anlam, bir nesne olmaktan çıkar, bir süreç hâlini alır. Yani bir bakıma, okuma eylemine denktir. Anlam, anlamak fiilinden bağımsız olarak bir eyleme dönüşür. Ĕ̆er anlam hiçbir metinde verili ve sabit değilse yazar da anlamı aynı okuma süreciyle edinmiş demektir. O hâlde yazma eylemi bile bir bakıma okuma eylemine dönüşür.

\subsubsection{Stanley Fish'in kuramına getirilebilecek eleştiriler}

Farkına varılacağı üzere Fish'in ortaya koyduğu estetik anlayış fazlasıyla özneldir. Üstelik Fish, bunun farkında olsa da (Moran, 2014: 98) okura kesin hatlarıyla çizilmiş bir sınır koymayı düşünmez. Yalnızca "daha geçerli" ya da "yönlendirici" (Eagleton, 2014: 248) bir üst yorumlayıcıyı tavsiye eder. Elbette bu üst yorumlayıcılar akademisyenlerdir. Anlamın metinde ya da dil ögelerinde içkin bir biçimde bulunduğunu kabul etmeyen bir kuram için üretilen anlamları ast-üst ilişkisine sokmak bir parça tutarsız bir tavırdır. Aslında burada Fish, Iser'e yaptığı nesnel kaygı eleştirisine düşmekten kaçınmaya çalışır. Fakat onun yönlendirici yorumlayıcısının, Iser'in ima edilen okurundan çok da farkı yoktur.

Martha C. Nussbaum, Fish'in kuramını, "aşırı rölativist ve radikal öznelci" olduğunu söyleyerek eleştirir (Nussbaum, 1990: 220-229). Nussbaum'a göre kuram, safsatadan öte bir şey değildir. Aslında bir metnin anlamını metinden ve yazardan tamamen koparmak ve onu yalnızca okurda aramak gerçekten de aşırı bir iddiadır. Küçük farklılıklar haricinde hemen hemen her okurun bir metinden çıkardığı anlam aynıyken metnin anlamsal varlığını tamamen görmezden gelmek gerçekçi bir tutum değildir. Üstelik böyle bir tutum estetik sorgulamalara da tatmin edici bir cevap vermez. Suç ve Ceza'nın neden bu kadar "güzel" olduğu Fish'in yaklaşımıyla açıklanamaz. Buna karşın Fish'in teorisinin bir kaçış noktası da vardır aslında. Eğer kuramı bir edebiyat ya da estetik kuramı olarak değil de bir dil kuramı olarak ele alırsak daha gerçekçi ve elle tutulur verilere ulaşabiliriz. 
Terry Eagleton da Fish'in kuramına benzer eleştiriler getirir. Yalnızca anlamın değil, dilsel ve biçimsel ögelerin bile okur tarafından oluşturulmasını, bunların yorumun ürünü olmasını Eagleton, "Fish'in okurken neyi yorumladığını zannettiği gibi ilginç bir soru"yla karşılar. Çok yerinde bir sorudur bu. Eğer okur tarafından şekillendirilinceye kadar ortada hiçbir şey yoksa okur aslında neyi şekillendiriyor olabilir ki? Dile her istenen anlamın verilebileceği yönündeki savı ise "basit bir fantezi” olarak açıklar Eagleton. “Çünkü bu tür metinler bir bütün olarak dile aittirler, onları ne kadar bozup ihlal etseler de yine de diğer dilsel pratiklerle karmaşık ilişkiler içindedirler; dil de, onunla canımız ne isterse yapabileceğimiz bir şey değildir". Ne de olsa insan, iliklerine kadar dil tarafından şekillendirilen bir yaratıktır. Düşünme eylemini bile dilden bağımsız yapamıyorken yorumlamayı onun referanslarından bağımsız olarak yapmamız düşünülemez (Eagleton, 2014: 98-100).

\title{
2. Alımlama Estetiği Kuramını Bir Metin Üzerinde Uygulama Çalışması
}

\section{1. Örnek metin: Turgut Uyar'ın “Hiçsizliğe" şiiri}

\author{
HiçSİZLIĞE \\ Tanrı sen ne kadar güzelsin \\ bir hiç olarak \\ ormansın belki bilmiyorum \\ belki ormanda bir ağaçsın şuncacık \\ bir pazartesi günüsün \\ insanları dupduru edemeyen \\ bütün karayollarında ve demiryollarında \\ gider gelirim bütün dünyada \\ ama biliyorum Kırşehir'de mezarsın \\ bir kilisesin Kapadokya'da \\ sözgelimi yumurtada zarsın \\ ustasın sabahları yapmada \\ en katı yoklukları koyarak insanın içine \\ akşamüstlerinde biraz gaddarsın \\ sular ve zamanlar kararırken \\ ne yapalım \\ bari bağışlayalım birbirimizi
}

\section{2. Örnek metnin alımlama estetiği kuramına göre yorumlanması}

Alımlama Estetiği her şeyden çok anlam olgusuna odaklanan bir kuramdır. O yüzden, Turgut Uyar'ın bir anlam arayışında olduğu sezilen bu şiirini örnek metin olarak kullanmak 
uygun olacaktır. Elbette buradaki anlam, Turgut Uyar'ın sahip olduğu anlamlardan farklı olacaktır. Sonuçta okur merkezli bir kuramdan bahsedilmektedir ve Iser, Jauss ve Fish'e göre "Hiçsizliğe" şiirinin anlamını oluşturan ancak ve ancak okurlar olabilir. Tabi kuramın öznelci, çoğulcu ve bireyci yapısından ötürü bu yorumlama esnasında çoğul bir özneyi varsaymak pek doğru olmayacak. Şiirin yorumlamasını Alımlama Kuramı'na göre yaparken tüm anlamın tekil öznede üretildiğini ve yorumun da bu üretimin bir sonucu olduğunu prensip olarak kabul etmek gerekecek.

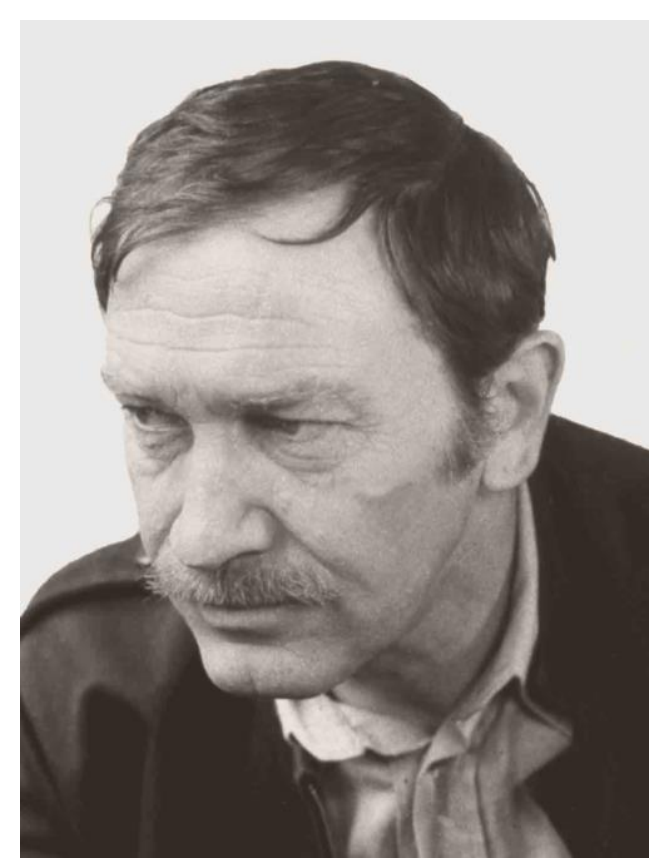

Turgut Uyar

Önce şiirin başlığı ele alınıp bunu üç kuramcının teorilerine göre alımlamak denenebilir. "Hiçsizliğe" sözcüğü, neresinden bakılırsa bakılsın karışık bir yapıya sahiptir. "Hiç" sözcüğüyle "-siz" eki anlamca birbirlerine çok yakındırlar. "Hiç", sıfır sayısının dilsel karşılığıdır. Genel olarak sıfır kez, sıfır adet, sıfır tane gibi anlamları vardır ve hem bir belirsizlik sıfatı hem de bir zarf olarak kullanılabilir. "-siz" eki ise eklendiği sözcüğe yokluk durumu anlamı katar. Bu bağlamda "-siz", hiç sözcügünün ekleşmiş hâlidir. "Anlamsız" sözcügüu, "hiç anlam" olarak da okunabilir. Üstelik “-siz" eki daima isimlere eklenirken burada eklenmiş olduğu "Hiç" sözcüğü bir isim değildir. "Hiçsiz" sözcüğü bu durumda kural dışı bir kullanımdır ve zaten ne bu sözcük ne de şiirin başlı̆̆ını oluşturan "hiçsizlik" sözcüğü TDK Yazım Kılavuzu'nda yer almaz. Ne var ki daha bu anda bile şiir, Alımlama kuramcılarını haklı çıkarır adeta. Çünkü Türkçe bilen hemen her okur bu sözcükten anlam çıkarmayı başaracaktır.

Çünkü buradaki kullanımında "hiç" sözcüğü "hiçbir şey" tümcesinin yerine kullanılmıştır. "Şey" bir isimdir ve sözcük "hiçbir şeysizlik" olarak okunursa hem kurallı bir kullanımda bulunulmuş olur hem de gayet açık bir anlam edinilebilir. Muhtemelen Wolfgang Iser, yazarın bu bağlantıyı kurma işini okura bıraktığını söyleyecektir. Haklı da olacaktır; çünkü az önce de söylendiği gibi okur bu anlamı zaten kolayca bulup çıkartır. Bulamayacak okur da bu şiirden uzak durmalıdır zaten. Çünkü besbelli şiirin "ima ettiği okur" o değildir. Yazar ve metin burada "hiçbir şeysizlik" anlamını açıkça ortaya koymuştur. Ona bakıp da "hiç" diye isimlendirilen bir tür meyvenin yokluğu, gibi bir anlam çıaran okur, yetkin bir okur olamaz. 
Jauss ise muhtemelen şiirin yazıldığı dönemde bu başlığın çeşitli yorumlanışlarına odaklanmak isteyecektir. Onun için bu sözcüğün ne anlam ifade ettiği ikinci plandadır. Önemli olan, yazıldığı dönemdeki okurun ona ne anlamlar yüklediğidir. Eğer genel olarak ortaya çıkan anlam bu yeni, alışılmadık kalıba uygunsa eser (en azından eserin başlığı) dönemin beklentiler ufkuna uygun olarak sayılacaktır. Bu dönemin ufku, eserin başlığının şu anda anlaşıldığı gibi anlaşılmasına yetkin değilse eser için bu defa "çağının ilerisinde" yorumu yapılacaktır. Yok, eğer zaten çoktandır kullanılmakta olan, iyice eskimiş ve kanıksanmış bir üslup örneğiyse, bu defa da onu "gerici" bir eser olarak kabul etmek mümkün olacaktır. Böylelikle yazıldığı dönemin beklentiler ufkuna dair bazı çıkarımlar yapılabilir. Daha sonra farklı dönemlere de aynı biçimde yaklaşılır ve tüm bu dönemlerden elde edilecek çıkarımlar birbirleriyle karşılaştırılır. Bu karşılaştırmanın sonucunda ortaya yeni bir edebiyat tarihi çıkacaktır.

Fish'in bu başlığa yaklaşımı ise çok daha özgürce olurdu. Eğer herhangi biri çıkıp bu başlık için, "'Hiçsizliğ' benim köpeğimin ismiydi ve şiirin başlığına bakınca bu şiirin benim köpeğime yazılmış olduğunu anlıyorum" biçiminde bir yorum yapsa bile Fish onu ilgiyle dinleyecektir. Çünkü ona göre bu yorum, başlığın sahip olduğu sonsuz olası yorumdan biridir. Gerçi akademisyenlerin bu başlıkla ilgili yaptıkları yorumlarla bu tuhaf yorum arasında bir tercih yapacak olsa akademisyenlere yakın duracaktır ama Hiçsizliğ isimli köpeğe ait yorumu da asla bir kenara atmaz.

Yalnızca başlık üzerinden yapılan bu yorumlamalar bile üç şahsiyetin kuramları hakkında fikir sahibi olmaya yetebilir. Anlamı tespit etmek adına okuru merkeze alıp bu kadar kılı kırk yaran araştırmalara girmek biraz gereksizmiş gibi görünebilir. Fakat unutmamak gerekir ki bu üç kuramın da asıl hedefi edebiyattır. Anlamı, edebî eserlerin ürettikleri bir olgu olarak değerlendirirler ya da onunla yalnız edebî eserlerin içindeyken uğraşırlar. Bu yüzden başlık üzerine yapılan çıkarımlar ancak bir alıştırmalık olarak kabul edilmeli. Metnin bir parçası olarak bu çıkarımlar da elbette önemlidir ama Alımlama'nın salt kelime ya da cümle çıkarımlarından ibaret olduğu da düşünülmemelidir.

Eserin bütünü üzerinde çalışırken öncelikle bir alımlama denemesi gerçekleştirmek gerekecek. Daha sonra şiirin neden böyle alımlanmış olabileceğini üç kuramcının adımlarını takip ederek çözme girişiminde bulunmak bazı uygulama biçimlerinin görülmesini olanaklı k1lacaktır.

Başlık bir umut çağrışımı uyandırır. Çünkü hiçlik korkutucu bir düşüncedir. Var olmak olgusu üzerine felsefe inşa eden insanoğlu "hiç"i asla tam olarak kavrayamaz zaten. Üstelik hiç, gerçek anlamında bilincin de yokluğu durumunu içerdiği için bilinçle kavranmasının imkânsız olduğu, tam manasıyla paradoksal bir sözcüktür. Bu bağlamda 
hiçsizlik, "hiç" diye bir şeyin olmadığı bir tanım kazanır ve "hiç" karşısında tedirgin olan insanoğlu bu tanımla beraber umutlanır.

Öte yandan ilk mısrayla beraber alımlama değişebilir. Metin Tanrı kavramıyla hiç kavramını özdeşleştirir. Bu durumda "hiçsizlik", "tanrısızlık” anlamı kazanır. O hâlde şiirin başlığı da "Tanrısızlığa” diye okunabilir. Üstelik Tanrı, hiç ile özdeşleştirilirken onun bu özdeşleşmeyle "ne kadar güzel” olduğundan bahsedilir. Tanrısızlık, tanrının olmayışı güzel midir öyleyse? Metnin bunu kastettiğine ilk iki mısrayla beraber ikna olunur.

Fakat ilk bölümün bittiği yere kadarki anlatı, algının bir kez daha değişmesine neden olur. İlk iki mısrada metnin kastettiği anlamdan eminken geri kalan kısımdaki anlatım sayesinde onun pek de emin olmadı̆̆1 sezilir. “Ormansın belki bilmiyorum” dizesiyle "belki ormanda bir ağaçsın şuncacık" dizesini beraber yorumlayıp varılan sonuç, metnin tanrıyı yoklukla özdeşleştirmesinden öte, varsa bile onun nitelikleri hakkında fikir sahibi olmayışı olarak yorumlanabilir. Orman ve ağaç kavramlarının arasındaki anlamsal ilişki küme-alt küme ilişkisi gibidir. Toplum ve insan ilişkisi de bu kavramsal benzetmeye uygundur. Fakat bu iki mısranın verdiği his, tanrının küme olmakla (kapsayan), alt küme olmak (kapsanan) arasındaki farkta sorgulanmış olmasıdır. Ne var ki bu sorgulamanın cevabı havada kalır. Çünkü metin, tanrının bu ikisinden hangisi olduğuna dair hiçbir fikre sahip değildir.

Beşinci dizedeki "pazartesi" sözcüğü, haftanın ilk iş günü olması dolayısıyla pek sevilmemesi dışında pek bir şey ifade etmez. Fakat onu altıncı dizeyle birleştirince bazı farklı alımlamalar yaşanabilir. Modern dünyada insanlar yaşamak için çalışmak, para kazanmak zorundadırlar. Bu yüzden sosyal hayat ekonomik dinamikler üzerine kurulmuştur. Hafta içi diye nitelenen beş gün, genel çalışma günleri, hafta sonu diye nitelenen iki günse tatil günleridir. Sosyal ve ekonomik bağlamda pek çok etkinlik bu genel kabule göre düzenlenir. İnsanlar hafta sonu dinlenirler, hafta içi kazanıp hak ettikleri parayı kendileri için harcarlar ya da en basit tabiriyle çalışmaktan başka şeyler yapmaya çabalarlar. Fakat pazartesiden itibaren bu süreç biter, beş günlük yeni bir çalışma dönemi başlar. Pazartesi, dinlenmeden çalışmaya geçişin bir sembolü gibidir ve bu yüzden belki de günler arasında en az sevilenidir. Bu döngü hep böyle sürecekmiş gibidir. İnsanlar devamlı çalışma yükümlülüğü altında hafta sonunun hayalini kurarak uğraşıp didinirler ve bitmesini istemedikleri hafta sonunun bitmesiyle yeniden ayn bekleme sürecine girerler. Tanrı ile pazartesi arasında bu yönde bir ilişki kurulabilir mi? Eğer mevcut dinler ele alınırsa bir bağlantı kurmak mümkün olacaktır. Dinler, insanları ibadete yönlendiren hatta bazı ibadetleri farz kılarak onların yaşam düzenlerini belli ölçüde şekillendiren kurumlardır. Bu yönlendirmenin ve farz kılmanın hedefinde ise ilahi bir ödül vardır. Yani insan yaşamak için ekonomik dinamiklere uyum sağlamak zorunda olduğu gibi dinlerin vaat ettiği öte yaşam için de farklı türde çalışmak durumundadırlar. Fakat bu manevi çalışma da bir döngü içerisindedir. O da hep 
böyle gelmiş, hep de böyle gidecek gibi görünür. Kısa ömürleri olan insanların bütün hayatlarını etkisi altında tutmayı öngörür. Tıpkı ekonomik hayat gibi o da boşluğu hoş görmez. Çalışmayan insan aç kalır, ibadet etmeyen insan da ilahi ödülden mahrum bırakılır. İşte tanrı kavramıyla pazartesi kavramı tam bu noktada özdeşleştirilebilir. İkisi de insana bir zorunluluk dayatırlar. Üstelik bu zorunluluk bütün yaşamları boyunca geçerli olacaktır. Yeterince çalışan bir insanın yaşamının geri kalanında çalışmak zorunda olmaması söz konusu değildir. Aynı şekilde yeterince ibadet eden bir insanın belli bir süreden sonra ibadet etmesine gerek kalmaması da söz konusu değildir. Bu sürüncemenin içinde insan asla hayatını gerçek bir özenlikle, tam anlamıla kendi arzuladığı gibi yaşayamaz; yani asla dupduru kalamaz.

Bundan sonraki dört mısrada ise bir ima sezinlenir. Bütün dünyayı gezen ve tanrı olgusunu dünyanın her yanında aramaması gerektiğini bilen birinin bir tür evrensellik göndermesi gibidir bu mısralar. Sanki metin, tanrı kavramının evrensel olmadığını, yerel özelliklere sahip olduğunu düşünüyor gibidir. Bu düşünce iki farklı şekilde dile getirilir. İlki ve daha bariz olanı, tüm dünya ve Kırşehir ile Kapadokya arasında yapılan evrensellikyerellik göndermesidir. Diğeri de karayolları ve demiryolları gibi modern dünyanın maddi ürünleriyle mezar ve kilise gibi eski ve manevi olguların kıyaslanmasında ortaya çıkar. Yani tanrı modern ve maddi dünyada var olan bir şey değil de eski ve manevi dünyada yaşayan bir şeydir. Bu kavramlar arasındaki tarihsel önlük-artlık ilişkisi de tanrının eski çağlarda kalmış, günümüzde geçerliliğini yitirmiş bir olgu olduğu düşüncesini hissettirir.

Bundan sonraki iki mısrada tanrı olgusuna başka bir pencereden, onun varsayılan mucizeleri irdelenerek bakılır. On birinci mısranın başındaki "sözgelimi" ibaresi bu kanııı oluşturan en önemli etkendir. "Sözgelimi yumurtada zarsın" cümlesini okur okumaz akıllara, “Ey yumurtaya can veren Tanrı'm” şeklindeki çok kullanılan söylem gelebilir. “Ustasın sabahları yapmada" dizesi ise Kur'an-1 Kerim'de geçen bir ayet olan ve her gün geceyi bir örtü gibi örtenin ve güneşi gökte yükseltenin Tanrı'nın ta kendisi olduğunu söyleyen dinsel bir inançla örtüştürülebilir. Metnin bunlara gönderme yaptığı düşünülebilir ve tanrı olgusunun böyle bir şey olduğunun söylenegeldiğine ama bunun söylemden öte bir gerçekliği olup olmadığı konusunda sorgulayıcı bir tavır takındığına kanaat getirilebilir.

Son üç mısra ise şiirsel bir söylemle ve biraz da sitem edercesine yazılmış sözlerden oluşuyor gibidir. Akşamüstleri, insanın ekonomik zorunluluklarını tamamladığı ve gün içinde kalan kısmın kendisine ait olduğu dönemlerin başlangıcıdır. Fakat öznelliğe kapı açan bu dönemde gün bitmek üzeredir. Işık azalır -bir süre sonra tamamen gider-, hava görece soğur, sosyal aktiviteler biter. Yani insan tam kendine vakit ayırma fırsatı bulmuşken bu vakti değerlendirme fırsatları epeyce azalır. Bu yüzden kendi kendiyle, düşünceleriyle baş başa kalır. Çoğu zaman bu düşünceler, toplum içinde ister istemez yıpranan insanın görece 
kötü anılarını hatırlayıp içlendiği, günün karanlığa dönmesi gibi farkında olmadan karanlığa dönen düşünceler olurlar. Fakat bu, metnin geride kalan bölümüne kıyasla çok daha öznel bir yorum gibidir. Metnin başından beri süregelen anlamlandırma çabasına duygusal bir son katmayı amaçlıyor gibidir. Yine de bu duygusal olumsuzluğu bile tanrıyla özdeşleştirme, en azından bu yönde bir sorgulama içine girme kaygısı içindedir.

Şiirin iki mısradan oluşan son bölümü ise bir uzlaşı anlamı taşır. Son mısrada geçen "bağışlamak" sözcüğü, anlamca en fazla düşündüren sözcüklerden biridir. "Affetmek" sözcüğü bağlamında anlamlandırılabilir fakat bunun şiirin genel yapısına uymadı̆ğ görülecektir. Bu sözcük daha çok "azletmek, serbest bırakmak" gibi bir anlam taşımaktadır. Baştan beri tanrının varlığı-yokluğu üzerinde düşünen ve varsa hangi niteliklere sahip olduğunu, yoksa da neden var olmadığını sorgulayan metin, bu son iki mısrayla beraber bu konuda daha fazla kafa yormak istemediğini ilan ediyor gibidir. Tanrı onu varlığına ikna edememiştir, bu yüzden ondan bu kararı için af diler. Fakat -varlığına inanmıyor gibi görünse de- var olmamasının ve var olmamasına rağmen varmış gibi düşünülmesinin onun suçu olmadığını düşünür ve bu yüzden kendi de onu affeder.

\subsection{Yorumlama sürecinin üç kuramcının teorileri üzerinden değerlendirilmesi}

Önce Stanley Fish ile başlamak bariz bir kolaylık sağlayacaktır. Çünkü yukarıda yapılan alımlama sürecimi en çabuk kabullenen kişi muhtemelen o olacaktır. Stanley Fish için -prensip olarak- bu yorumda yadırganacak, dışlanacak, kabul görmeyecek hiçbir bölüm yoktur. Çünkü Fish, anlamı yalnızca okurda arar ve bunun için de hemen hemen hiçbir ön şart aramıyor gibi görünür. Elbette bu yorum "daha üstün okurlar"1n yani akademisyenlerin üreteceği yorumlara yakın olduğu için diğer pek çok yorumdan daha üstün olacaktır onun gözünde. Öte yandan "Hiçsizliğe" şiirine bakıp “Hiçsizliğ" isimli merhum köpeğe dair anlamlar çıkartılmış olsaydı bile buna karşı tutumu pek farklı olmazdı. Fish'e göre, bu metne bakıp gitar akorları çıkartılmış olsaydı bile pek sorun olmazdı zaten. Onun kuramına göre "Hiçsizliğe" şiirinden edinilen yukarıdaki alımlama süreciyle ondan gitar akorları alımlayan kişinin okuma süreci birbirine eş eylemlerdir. Her iki durumda da anlam gerçekleşmiştir.

Jauss ise öncelikle metnin yazıldığı dönemi sorgulayacaktı şüphesiz. Yukarıdaki alımlama sürecini ele almadan önce şiirin yazıldığı dönemdeki ya da yazıldığı dönemle bu makalenin yazıldığı dönemin arasında kalan bir dönemdeki -hatta mümkünse ikisininkini birden- yorumları okumak isteyecekti. Çünkü Jauss'un "Beklentiler Ufku” kuramına göre asıl incelenmesi gereken şey tek tek alımlama süreçlerinden ziyade farklı dönemlerdeki okurların alımlama süreçleri arasındaki farktır. Bu yüzden yukarıdaki alımlama sürecinin tek başına bir değeri yoktur onun için. Şiirin yazıldığı dönemde aldığ 
alımlama tepkilerini karşılaştırır. Onun varacağı bütün sonuçlar bu karşılaştırma üzerinden gerçekleşecektir.

Wolfgang Iser ise öncelikle yukarıdaki alımlama sürecine, şiirin ima ettiği okur tipi olup olmama durumunu soruşturarak başlayacaktır. Yapılan çıkarımların metinle uyumluluğunu denetleyecek, metinde gördüğü "boş alanlar"ın ve "bilinmezlikler"in fark edilip edilmediğini, fark edildiyse bu boşlukların nasıl doldurmuş olduğunu tespit etmeye çalışacaktır. Örneğin, "sözgelimi yumurtada zarsın” dizesinden yukarıda alımlanan ve mucize kavramına referanslanan anlamı mutlaka biraz zorlamak isteyecektir. Çünkü farklı kültürlerin temsilcileri olarak yukarıdaki alımlayıcı tarafından iyi bilinen "Ey yumurtaya can veren Tanrı' $m$ " tabirini Iser' in hiç bilmiyor olması çok normaldir. Kendi alımlama sürecinde, mesela, bu dizenin ileri teknoloji-tanrı ilişkisine gönderme yaptığını (bugün teknoloji sayesinde sırlarına vakıf olunan ve muadilinin üretilmesi yine bu sayede başarılan yumurta zarının fi tarihinden beri tavuklar tarafından üretiliyor olmasını mucize olarak yorumlama durumuna atıfta bulunma) düşünmüş olsun. Tutup da kendi alımlama sürecinden vazgeçmeyecektir muhtemelen ama yukarıdaki alımlama sürecini de doğru kabul edecektir. Çünkü çıkarılan bu iki anlam birbirine yakındır ve bunun ötesinde dizede verilen "gücül” anlama gayet uymaktadır. Fakat bu noktada uzlaşılsa bile başka anlam çıkarımlarında metinle ters düşülmüş olabilir. Iser için bu bir sorundur. Çünkü iki anlam arasında metnin sunduğu ortak bir bağlam yoksa alımlama süreçlerinden en az biri hatalıdır demektir. $\mathrm{Ne}$ var ki bu hatanın hangi tarafta olduğunu tespit edebilecek sağlam bir yöntem koymaz ortaya. Çünkü ortaya koyduğu teori "artistik uç"la "estetik uç" arasında belli bir uyumu gerektirmektedir. Fakat çoktan ölmüş olan Turgut Uyar'a ulaşmak söz konusu olmadığı için bu uyumu tam anlamıla denetleme imkânı da olmayacaktır.

\section{Sonuç}

Postmodernizmin okura dönük yapısı, okuru merkeze alan kuramların ve eleştiri disiplinlerinin oluşmasını ve önem kazanmasını kaçınılmaz olarak sağlamıştır. Her şeyden önce, yazarın da en nihayetinde bir okur olduğu gerçeği vardır ki postmodern metinler tamamen bu bilinçlilik üzerine kurulur. Çünkü metinlerarasılık, diyalojizm, üst kurmaca gibi yazım teknikleri, metnin nezdinde yazarı okurla neredeyse bir seviyeye getirir. Yazar okurla, okur da yazarla sık sık yer değiştirir. Üstelik anlamın oluşum süreci gibi karmaşık sorunlar yalnızca yazarla ya da metinle çözülemeyecek denli zorlaşmıştır. Günümüzün felsefe dünyası her şeyden çok dile, dolayısıyla anlama eğilmişken (çünkü doğa felsefesi artık neredeyse tamamen yerini bilime biraktı) (Hawking, 2016: 227) ve yapisalcılık ve postyapısalc1lık gibi anlam olgusuna duyulan güveni kökten sarsan kuramlar ortaya çıkmışken anlamla ilgili eski usul tanımlar yapılıp durması beklenemezdi zaten. 
Alımlama Estetiği, bu arayışa okuru da dâhil etmek hususunda başarı sağladı. Bir bütün olarak ele alındığında ne Iser'in ne Jauss'un ne de Fish'in kuramları genel-geçer olamamış, pek çok yönden eksik kalmışlardır ama savundukları tezleri alt başlıklar hâline getirince edebiyata ve dil felsefesine yaptıkları katkıyı görmemek mümkün değildir.

Anlam, Iser'in dediği gibi yazarın bıraktığı boşlukların okur tarafından doldurulması sonucunda oluşur; fakat tek oluşma biçimi bu değildir. Yapısalcılığı, postyapısalcılığı, Rus biçimciliğini, fenomenolojiyi, feminist eleştiri kuramını, Marksizmi hatta romantizmi hesaba katmadan anlam konusunda hüküm vermek doğru olmayacaktır. Jauss'un "beklentiler ufku" pek çok şeyi açıklar; fakat her şeyi açıklayabilmekten epeyce uzaktır. Fish ise Nussbaum'un iddia ettiğinin aksine tamamen "safsata" üretmiş değildir. Anlamın tüm yükünü okura yüklemek pek ele avuca gelir bir sav değilse de anlamın okurla olan ilişkisi hakkında daha geniş bir bakış açısı edinebilmemiz adına onun kuramı son derece değerlidir.

Alımlama Estetiği'nin, "edebiyat nedir?" ve "edebiyat ne işe yarar?" sorularına cevap üretebildiğini iddia etmek doğru olmayacaktır. Fakat bu soruların kapsamına okurun da görkemli biçimde giriş yapmasını sağlamışlardır. Bu noktadan sonraki hiçbir kuramın okuru eski konumuna gönderme cüretini gösterebileceğini, yukarıdaki sorulara bu şekilde cevaplar bulabileceğini düşünmek pek mümkün görünmemektedir. Alımlama Estetiği'nin edebiyat bilimine yaptığı yegâne katkı bu olsaydı bile bunun büyük bir katkı olduğu inkâr edilemezdi.

\section{Kaynakça}

Buchanan, Ian (2010). A Dictionary of Critical Theory. Oxford: Oxford University Press.

Deneau, Daniel P (1980). "Wolfgang Iser", The International Fiction Review. C. 7, Kanada:

Public Knowledge Project. https://journals.lib.unb.ca>ifr>download [erişim 18.11.2016].

Eagleton, Terry (2014). Edebiyat Kuramı - Giriş. çev. Tuncay Birkan. İstanbul: Ayrıntı Yayınları.

Ecevit, Yıldız (2004). Türk Romanında Postmodernist Açılımlar. İstanbul: İletişim Yayınları. Eco, Umberto (1991). Alımlama Göstergebilimi. çev. Sema Rifat. İstanbul: Düzlem Yayınları.

Encyclopædia Brittanica, “Stanley Fish”, https://global.britannica.com/biography/StanleyFish [erişim 22.11.2016].

Hawking, Stephen (2016). Zamanın Kısa Tarihi. İstanbul: Alfa Yayınları.

Kagan, Moissej (1982). Güzellik Bilimi Olarak Estetik ve Sanat. çev. Aziz Çalışlar. İstanbul: Altın Kitaplar Yayınevi.

Koç, Turan (2009). "Sanat", İslam Ansiklopedisi. c. 36. İstanbul: MEB www.islamansiklopedisi.info/index.php?klme=Sanat [erişim 12.11.2016].

Moran, Berna (2014). Edebiyat Kuramları ve Eleştiri. İstanbul: İletişim Yayınları. 
Nussbaum, Martha C. (1990). Love's Knowledge. New York: Oxford University Press.

Okay, Orhan (1990). Sanat ve Edebiyat Yazıları. İstanbul: Dergâh Yayınları.

Oxford University Press (2016). "Hans Robert Jauss". oxfordindex.oup.com/view/10.1093/oi/authority.20110803100018291 [erişim 22.11.2016]. Özbek, Yılmaz (2013). Post-modernizm ve Alımlama Estetiği. Konya: Çizgi Kitabevi Yayınları.

Shi, Yanling (2013). "Review of Wolfgang Iser and His Reception Theory", Theory and Practice In Language Studies. Finlandiya: Academy Publisher. www.academypublication.com>vol03 [erişim 18.11.2016].

Shiner, Larry (2013). Sanatın İcadı. çev. İsmail Türkmen. İstanbul: Ayrıntı Yayınları.

Şimşek, İsmail (2014). "Antikçağdan Alman İdealizmine; Estetik Bir Değer Olarak Güzellik”, Atatürk Üniversitesi İlahiyat Fakültesi Dergisi. s. 41. Erzurum. http://dergipark.gov.tr/download/article-file/31210 [erişim 18.02.2017].

Tatar, Burhanettin (2001). "Hans-Georg Gadamer ve Hakikat ve Yöntem Adlı Eseri”, On Dokuz Mayıs Üniversitesi Dergisi. www.dergipark.ulakbim.gov.tr/omuifd/article/ [erişim 24.11.2016].

Thiselton, Anthony C. (2006). Thiselton On Hermeneutics: The Collected Works and News Essays of Anthony Thiselton. Hampshire, UK: Ashgate Publishing.

Türk Dil Kurumu. "Sanat", Genel Türkçe Sözlük, www.tdk.gov.tr/index.php?option=com_gts\&arama=gts\&guid=TDK.GTS.5827508044e b66.56890130, [erişim 12.11.2016].

Uyar, Turgut (2011). Büyük Saat. İstanbul: Yapı Kredi Kültür Sanat Yayıncılık. 